\title{
MODEL NON REKURSIF DALAM ANALISIS JALUR
}

\author{
DINIE ANEFI HAJARA, IZZATI RAHMI HG, FERRA YANUAR \\ Program Studi S1 Matematika, \\ Fakultas Matematika dan Ilmu Pengetahuan Alam, Universitas Andalas, \\ Kampus UNAND Limau Manis Padang, Indonesia. \\ email : diniehajara@gmail.com,izzatirahmihg@sci.unand.ac.id,ferrayanuar@sci.unand.ac.id
}

Diterima 29 November 2019 Direvisi 3 Desember 2019 Dipublikasikan 12 Januari 2020

\begin{abstract}
Abstrak. Analisis jalur adalah suatu teknik penggambaran dan pengujian model hubungan antar variabel yang berbentuk sebab akibat, yang dikembangkan dari analisis regresi sebagai metode untuk mempelajari pengaruh langsung atau tidak langsung dari variabel bebas terhadap variabel terikat. Jika ditinjau dari hubungan peubahnya, analisis jalur terbagi menjadi model rekursif dimana hubungan sebab akibat bergerak satu arah dan model non rekursif dimana hubungan sebab akibat bergerak dua arah atau timbal balik. Untuk menduga koefisien jalur model rekursif bisa digunakan metode Ordinary Least Squares (OLS), namun untuk model non rekursif penggunaan metode OLS tidak layak digunakan karena akan menghasilkan koefisien yang bias dan inkonsisten. Oleh karena itu, untuk menduga koefisien model non rekursif digunakan metode pendugaan lain salah satunya Two-Stage Least Squares (2SLS), yang merupakan pengembangan dari metode OLS. Pada penelitian ini untuk menduga koefisien model non rekursif digunakan metode jalur dan metode 2SLS dengan menggunakan data bangkitan. Hasil yang diperoleh dengan kedua metode ini tidak jauh berbeda, sehingga metode 2SLS menjadi metode alternatif untuk menduga koefisien jalur model non rekursif.
\end{abstract}

Kata Kunci: Analisis jalur, model non rekursif, Two-Stage Least Squares (2SLS)

\section{Pendahuluan}

Analisis jalur atau juga dikenal dengan sebutan path analysis yang dikembangkan oleh seorang ahli genetika bernama Sewall Wright yang merupakan perluasan dari analisis regresi sebagai metode untuk mempelajari pengaruh (efek) secara langsung dan tidak langsung dari variabel bebas terhadap variabel terikat. Ditinjau dari hubungan peubahnya, model pada analisis jalur terbagi menjadi model rekursif dimana hubungan sebab akibat bergerak satu arah dan model non rekursif dimana hubungan sebab akibat bergerak dua arah atau timbal balik.

Pendugaan koefisien jalur model non rekutsif dengan metode Ordinary Least Squares (OLS) tidak tepat digunakan untuk menduga parameter model non rekursif. Apabila metode Ordinary Least Squares (OLS) digunakan untuk menduga parameter persamaan simultan, maka akan dihasilkan dugaan parameter yang bias

*penulis korespondensi 
dan inkosisten [1]. Oleh karena itu akan digunakan salah satu pendugaan alternatif untuk menduga koefisien jalur model non rekursif yaitu metode Two Stage Least Squares (2SLS) [5].

\section{Analisis Jalur}

Analisis jalur adalah suatu teknik yang dikembangkan oleh seorang ahli genetika bernama Sewall Wright, yang merupakan perluasan dari analsis regresi yang digunakan untuk menganalisis pola hubungan antar variabel dengan tujuan untuk mengetahui pengaruh langsung dan tidak langsung dari variabel bebas terhadap variabel terikat [3].

Pada analisis jalur dikenal beberapa variabel, pertama variabel eksogen, yaitu semua variabel yang menjadi pengaruh atau variabel penyebab atau variabel bebas. Jenis variabel kedua adalah variabel endogen, yaitu variabel yang dipengaruhi oleh variabel eksogen atau variabel terikat. Selain itu juga dikenal variabel perantara, yaitu variabel yang menjembatani variabel eksogen dengan variabel endogen, biasa disebut juga dengan variabel penghubung. Keempat adalah variabel galat, yaitu menyatakan ragam yang tidak dapat diterangkan oleh model atau disebut dengan kesalahan pengukuran. Dalam analisis jalur, variabel-variabel tersebut memiliki hubungan baik secara langsung dan tidak langsung. Pengaruh langsung adalah pengaruh dari variabel eksogen ke variabel endogen secara langsung tanpa adanya variabel perantara. Pengaruh tidak langsung adalah pengaruh antara variabel eksogen terhadap variabel endogen yang melalui satu atau lebih variabel perantara $[2]$.

Diagram jalur adalah alat untuk melukiskan secara grafis, struktur hubungan kausalitas antar variabel eksogen, variabel penghubung dan variabel endogen. Untuk merepresentasikan hubungan kausalitas diagram jalur menggunakan simbol anak panah berkepala satu (single-headed arrow), ini mengindikasikan adanya pengaruh langsung antara variabel eksogen dengan variabel endogen. Anak panah ini juga menghubungkan error dengan variabel endogen. Untuk merepresentasikan hubungan korelasi atau kovarian diantara dua variabel menggunakan garis lengkung dengan anak panah berkepala dua di kedua ujungnya (two-headed arrow) [4].

Koefisien jalur adalah koefisien yang menunjukkan pengaruh variabel eksogen terhadap variabel endogen yang telah tersusun dalam diagram jalur. Bila dalam diagram jalur terdapat dua atau lebih variabel, maka dapat dihitung koefisien parsialnya, dengan menggunakan data yang telah dibakukan atau dengan matriks korelasi $[3]$.

Sebagai ilustrasi perhitungan koefisien jalur digunakan empat variabel, yaitu $X_{1}$, $X_{2}, X_{3}$ dan $X_{4}$, dengan semua variabel merupakan variabel yang sudah dibakukan, $X_{i} \sim N(0,1), i=1,2,3,4$ dan diilustrasikan dengan diagram jalur pada Gambar (1). Dari diagram jalur pada Gambar (1) maka model untuk empat variabel tersebut bisa dibentuk menjadi persamaan struktural berikut:

$$
\begin{aligned}
& X_{2}=\beta_{21} X_{1}+u \\
& X_{3}=\beta_{31} X_{1}+\beta_{32} X_{2}+v \\
& X_{4}=\beta_{41} X_{1}+\beta_{42} X_{2}+\beta_{43} X_{3}+w
\end{aligned}
$$




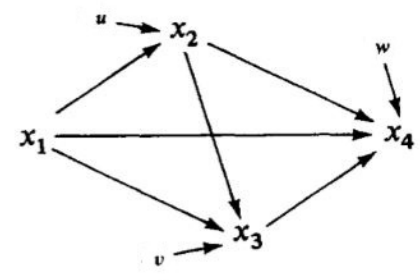

Gambar 1. Diagram jalur.

Untuk menghitung koefisien jalur, langkah yang perlu dilakukan pertama mengalikan persamaan struktural variabel endogen dengan variabel eksogen yang mempengaruhinya kemudian menghitung nilai harapannya. Karena variabel yang digunakan adalah variabel yang dibakukan maka $E\left(X_{i}^{2}\right)=1, E\left(X_{i} u\right)=0$ dan $E\left(X_{i} X_{j}\right)=\rho_{i j}$ untuk $i, j=1,2,3,4$. Maka diperoleh koefisen jalur sebagai berikut:

$$
\begin{array}{ll}
\rho_{31}=\frac{\rho_{13}-\rho_{12} \rho_{23}}{1-\rho_{12}^{2}} & \beta_{32}=\frac{\rho_{23}-\rho_{12} \rho_{13}}{1-\rho_{12}^{2}} \\
\beta_{41}=\frac{1}{D}\left|\begin{array}{ccc}
\rho_{14} & \rho_{12} & \rho_{13} \\
\rho_{24} & 1 & \rho_{23} \\
\rho_{34} & \rho_{23} & 1
\end{array}\right| & \beta_{42}=\frac{1}{D}\left|\begin{array}{ccc}
1 & \rho_{14} & \rho_{13} \\
\rho_{12} & \rho_{24} & \rho_{23} \\
\rho_{13} & \rho_{34} & 1
\end{array}\right| \\
\beta_{43}=\frac{1}{D}\left|\begin{array}{ccc}
1 & \rho_{12} & \rho_{14} \\
\rho_{12} & 1 & \rho_{24} \\
\rho_{13} & \rho_{23} & \rho_{34}
\end{array}\right| & \text { dimana } D=\left|\begin{array}{ccc}
1 & \rho_{12} & \rho_{13} \\
\rho_{12} & 1 & \rho_{23} \\
\rho_{13} & \rho_{23} & 1
\end{array}\right|
\end{array}
$$

\section{Two-Stage Least Squares}

Analisis regresi Two-Stage Least Squares (2SLS) adalah teknik statistik yang digunakan dalam analisis persamaan struktural. Teknik ini merupakan pengembangan dari metode Ordinary Least Squares (OLS). Metode ini digunakan saat error dari variabel terikat berkorelasi dengan variabel bebasnya. Selain itu, metode ini berguna ketika ada putaran timbal balik dalam model.

Misalkan terdapat persamaan regresi linier sebagai berikut:

$$
Y=\beta_{0}+\beta_{1} X_{1}+\beta_{2} X_{2}+\beta_{3} X_{3}+\varepsilon
$$

Diasumsikan pada model diatas error $\varepsilon$ berkorelasi dengan salah satu variabel bebas, misalkan $X_{1}$. Tahap pendugaan parameter dengam metode 2SLS adalah sebagai berikut:

(1) Membentuk variabel instrumental untuk menggantikan variabel yang bermasalah. Kemudian meregresi $Z_{1}, X_{2}$ dan $X_{3}$ terhadap $X_{1}$ untuk memperoleh $\widehat{X_{1}}$.

$$
\widehat{X_{1}}=\gamma_{0}+\gamma_{1} Z_{1}+\gamma_{2} X_{2}+\gamma_{3} X_{3}
$$


(2) Masukkan kembali nilai $\widehat{X_{1}}$ yang bersesuaian dari persamaan di atas ke dalam persamaan regresi linier di awal.

$$
Y=\beta_{0}+\beta_{1} \widehat{X_{1}}+\beta_{2} X_{2}+\beta_{3} X_{3}+v
$$

\section{Model Hipotesis}

Pada penelitian ini model hipotesis dibentuk dari empat buah variabel dimana satu pasang variabel diantaranya memiliki hubungan sebab akibat dua arah atau timbal balik. Untuk model non rekursif yang dibentuk ini, dimisalkan $X_{3}$ dan $X_{4}$ memiliki pengaruh sebab akibat yang timbal balik, model diasumsikan dalam bentuk diagram berikut:

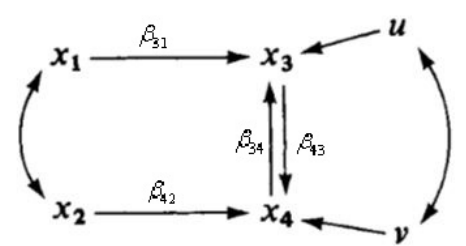

Gambar 2. Diagram jalur model hipotesis non rekursif

Sehingga model dihipotesiskan menjadi:

$$
\begin{aligned}
& X_{3}=\beta_{31} X_{1}+\beta_{34} X_{4}+u \\
& X_{4}=\beta_{42} X_{2}+\beta_{43} X_{3}+v
\end{aligned}
$$

\section{Pendugaan Koefisien Model Non Rekusif dengan Metode Jalur}

Dengan mengadopsi langkah-langkah pendugaan koefisen jalur pada model rekursif, maka akan dilakukan pendugaan koefisien jalur untuk model hipotesis, yaitu pada Persamaan (4.1) dan Persamaan (4.2). Dari diagram jalur model non rekursif, yaitu pada Gambar (2) diketahui bahwa variabel eksogen yang mempengaruhi $X_{3}$ secara langsung adalah $X_{1}$ dan secara tidak langsung adalah $X_{2}$. Untuk persamaan $X_{4}$, variabel eksogen yang mempengaruhi $X_{4}$ secra langsung adalah $X_{2}$ dan secara tidak langsung adalah $X_{1}$. Dengan mengalikan Persamaan (4.1) dan (4.2) dengan variabel eksogen yang mempengaruhinya dan kemudian hitung nilai harapannya. Karena variabel yang digunakan adalah variabel yang telah dibakukan maka $E\left(X_{i}^{2}\right)=1$, $E\left(X_{i} u\right)=0$ dan $E\left(X_{i} X_{j}\right)=\rho_{i j}$ untuk $i, j=1,2,3,4$. Sehingga koefisien jalur $\beta$ dari Persamaan (4.1) dan Persamaan (4.2) adalah sebagai berikut:

$$
\begin{array}{rlrl}
\beta_{31} & =\frac{\rho_{13} \rho_{24}-\rho_{14} \rho_{23}}{\rho_{11} \rho_{24}-\rho_{12} \rho_{14}} & \beta_{34} & =\frac{\rho_{11} \rho_{23}-\rho_{12} \rho_{13}}{\rho_{11} \rho_{24}-\rho_{12} \rho_{14}} \\
\beta_{42}=\frac{\rho_{14} \rho_{23}-\rho_{13} \rho_{24}}{\rho_{12} \rho_{23}-\rho_{13} \rho_{22}} & \beta_{43}=\frac{\rho_{12} \rho_{24}-\rho_{14} \rho_{22}}{\rho_{12} \rho_{23}-\rho_{13} \rho_{22}}
\end{array}
$$


Ilustasi pendugaan koefisen jalur untuk model non rekursif pada lima ratus data sampel yang sudah dibangkitkan dengan memasukkan nilai korelasi dari masingmasing variabel dan memasukkan nilai korelasi tersebut ke dalam Persamaan (5.1) Persamaan (5.2) maka diperoleh pendugaan model dengan metode jalur adalah sebagai berikut:

$$
\begin{aligned}
& \widehat{X_{3}}=-0.666537757 X_{1}+1,254230284 X_{4} \\
& \widehat{X_{4}}=-1,950487809 X_{2}+2,948457315 X_{3}
\end{aligned}
$$

\section{Pendugaan Koefisien Model Non Rekusif dengan Metode 2SLS}

Berdasarkan model hipotesis yang diilustrasikan pada Gambar (2) maka secara konsep langkah untuk pendugaan koefisien jalur model non rekursif metode 2SLS adalah sebagai berikut:

(1) Regresikan setiap variabel endogen dengan semua variabel eksogen dalam model dengan menggunakan metode OLS. Pada model hipotesis yang digunakan pendugaan parameter yang diperoleh digunakan untuk membentuk variabel instrumental $Z_{1}$ dan $Z_{2}$, yaitu:

$$
\begin{aligned}
& Z_{1}=\widehat{X}_{3}=b_{31} X_{1}+b_{32} X_{2} \\
& Z_{2}=\widehat{X}_{4}=b_{41} X_{1}+b_{42} X_{2}
\end{aligned}
$$

Variabel instrumental ini tidak akan berkorelasi dengan error pada model hipotesis awal.

(2) Masukkan nilai variabel intrumental yang bersesuaian dari Persamaan (6.1) dan Persamaan (6.2) ke dalam persamaan hipotesis model non rekursif, yaitu Persamaan (4.1) dan Persamaan (4.2), maka diperoleh:

$$
\begin{aligned}
& X_{3}=\beta_{31} X_{1}+\beta_{34} Z_{2}+u \\
& X_{4}=\beta_{42} X_{2}+\beta_{43} Z_{1}+v
\end{aligned}
$$

Selanjutnya proses pendugaan parameter untuk model pada Persamaan (6.3) dan Persamaan (6.4) bisa digunakan dengan metode OLS untuk memperoleh koefisien jalur model non rekursif.

Untuk ilustrasi pendugaan koefisien jalur model non rekursif dengan metode 2SLS akan digunakan bantuan aplikasi SPSS, akan diduga koefisen jalur yang mempengaruhi variabel eksogen pada model hipotesis, yaitu pada Persamaan (4.1) dan Persamaan (4.2).

(1) Pendugaan koefisien untuk persamaan $X_{3}$

Untuk analisa dari variabel $X_{3}$ yaitu pada Persamaan (4.1) diperoleh nilai Korelasi antara $X_{3}$ dengan $X_{1}$ dan $X_{4}$ sebesar 0,886 dan Koefisien Determinasi $\left(R^{2}\right)$ sebesar 0,785 . 
Tabel 1. Analisis Ragam dari Variabel Endogen $X_{3}$

\begin{tabular}{|c|c|c|c|c|c|}
\hline & Jumlah Kuadrat & df & Kuadrat Tengah & F & Sig. \\
\hline Regresi & 74624.010 & 2 & 37312.005 & 906.468 & .000 \\
Galat & 20457.496 & 497 & 41.162 & & \\
Total & 95081.505 & 499 & & & \\
\hline
\end{tabular}

Tabel 2. Nilai Koefisien Model dari Variabel $X_{3}$

\begin{tabular}{|c|c|c|c|}
\hline Koefisien & Beta & $\mathrm{t}$ & Sig. \\
\hline$X_{1}$ & -.667 & -22.835 & .000 \\
$X_{4}$ & 1.255 & 41.921 & .000 \\
\hline
\end{tabular}

Sehingga diperoleh model dugaan untuk $X_{3}$ adalah sebagai berikut:

$$
\widehat{X_{3}}=-0.667 X_{1}+1,255 X_{4}
$$

(2) Pendugaan koefisien untuk persamaan $X_{4}$

Untuk dari variabel $X_{4}$ yaitu pada Persamaan (4.2) diperoleh nilai Korelasi antara $X_{4}$ dengan $X_{2}$ dan $X_{3}$ sebesar 0,663 dan Koefisien Determinasi $\left(R^{2}\right)$ sebesar 0,401 .

Tabel 3. Analisis Ragam dari Variabel Endogen $X_{4}$

\begin{tabular}{|c|c|c|c|c|c|}
\hline & Jumlah Kuadrat & df & Kuadrat Tengah & F & Sig. \\
\hline Regresi & 90374.844 & 2 & 45187.922 & 166.371 & .000 \\
Galat & 134990.092 & 497 & 271.610 & & \\
Total & 225365.937 & 499 & & & \\
\hline
\end{tabular}

Tabel 4. Nilai Koefisien Model dari Variabel $X_{4}$

\begin{tabular}{|c|c|c|c|}
\hline Koefisien & Beta & $\mathrm{t}$ & Sig. \\
\hline$X_{2}$ & -1.949 & -9.783 & .000 \\
$X_{3}$ & 2.946 & 13.557 & .000 \\
\hline
\end{tabular}

Sehingga diperoleh model dugaan untuk $X_{4}$ adalah sebagai berikut:

$$
\widehat{X_{4}}=-1,949 X_{2}+2,946 X_{3}
$$

Dari hasil ilustrasi pendugaan koefisien jalur model non rekursif dengan metode jalur, yaitu pada Persamaan (5.3) dan Persamaan (5.4) dan dengan metode 2SLS, yaitu pada Persamaan (6.5) dan Persamaan (6.6) dapat terlihat hasil pendugaan 
14 Dinie Anefi Hajara, dkk

yang tidak jauh berbeda. Berarti metode 2SLS bisa menjadi salah satu metode alternatif untuk menduga koefisien jalur model non rekursif dalam analisis jalur.

\section{Kesimpulan}

Berdasarkan ilustrasi pendugaan koefisien kedua metode pada data bangkitan diperoleh pendugaan koefisien dengan metode jalur dan metode 2SLS memberikan hasil pendugaan yang tidak jauh berbeda. Dengan demikian, metode 2SLS dapat menjadi salah satu metode alternatif untuk menduga koefisien jalur dalam model non rekursif. Langkah untuk pendugaan koefisien dengan metode 2SLS yang pertama adalah membentuk variabel intrumental lalu meregresi variabel eksogen dan variabel instrumental terhadap variabel yang digantikan. Langkah selanjutnya adalah memasukkan hasil regresi ke variabel instrumental yang bersesuaian ke dalam persamaan regresi awal kemudian menduga koefisien dengan metode pendugaan koefisien yang bersesuaian.

\section{Daftar Pustaka}

[1] Berry, W. D. 1984. Nonrecursive Causal Models. Sage Publication, California

[2] Sarwono, J. 2007. Analisis Jalur untuk Riset Bisnis dengan SPSS. Andy, Yogyakarta

[3] Sarwono, J. 2011.Mengenal path analysis: sejarah, pengertian dan aplikasi. Jurnal Ilmiah Manajemen Bisnis. Vol. 11, No. 2: 285-296

[4] Usman, M. 2009. Model Linier Terapan Analisis Regresi, Perubahan Modul dan Analisis Jalur (Path Analiysis). Sinar Baru ALGENSINDO, Bandung

[5] Williams, R. $2005 . \quad$ Nonrecursive models (Extended Version). https://www3.nd.edu/ rwilliam/ (diakses 20 Januari 2019) 